\title{
JUURNAL.RU
}

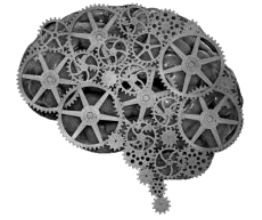

COMPANY GROUP "INTELLEKT"

Воробьев В.С., Синицына А.С.
Сибирский государственный университет путей сообщения Новосибирск, Россия

doi: 10.18411/lj2016-7-2-02

idsp 000001: lj2016-16-2-02

\section{Состояние жилищного фонда г. Новосибирска и мероприятия по исключению ошибок технического и организационно-технологического проектирования, строительства и эксплуатации}

\begin{abstract}
Новосибирск является крупным мегаполисом с проблемами урбанизированных территорий, напримерв соответствии с постановлением мэрии г. Новосибирска, плотность населения в жилом микрорайоне не должна превышать 420 человек на 1 гектар при обеспеченности 18-24 кв м на человека. К этим нормативам сведена социальная инфраструктура - количество детсадов, школ, больниц и т.п. В Новосибирске такой показатель нарушен в 2-3 раза. «В городе с 2009 года согласуются застройки 930, 1100, 1140, 1107, 1300, есть даже 1660 человек на 1 гектар».
\end{abstract}

Несмотря на высокую плотность застройки по данным комитета жилищно - коммунального хозяйства при администрации г. Новосибирска в муниципальном жилищном фонде по состоянию на1 января 2016 г. с износом от 0\% до 30\%находятся 27 750,8 тыс.кв.м; с износом от 30\% до 65\% находится 9 692,7 тыс.кв.м; с износом свыше 65\% износа находится 455,3 тыс.кв.м.

Ниже на рисунке 1 приведены статические данные по проценту износа жилого фонда за 10 лет. 


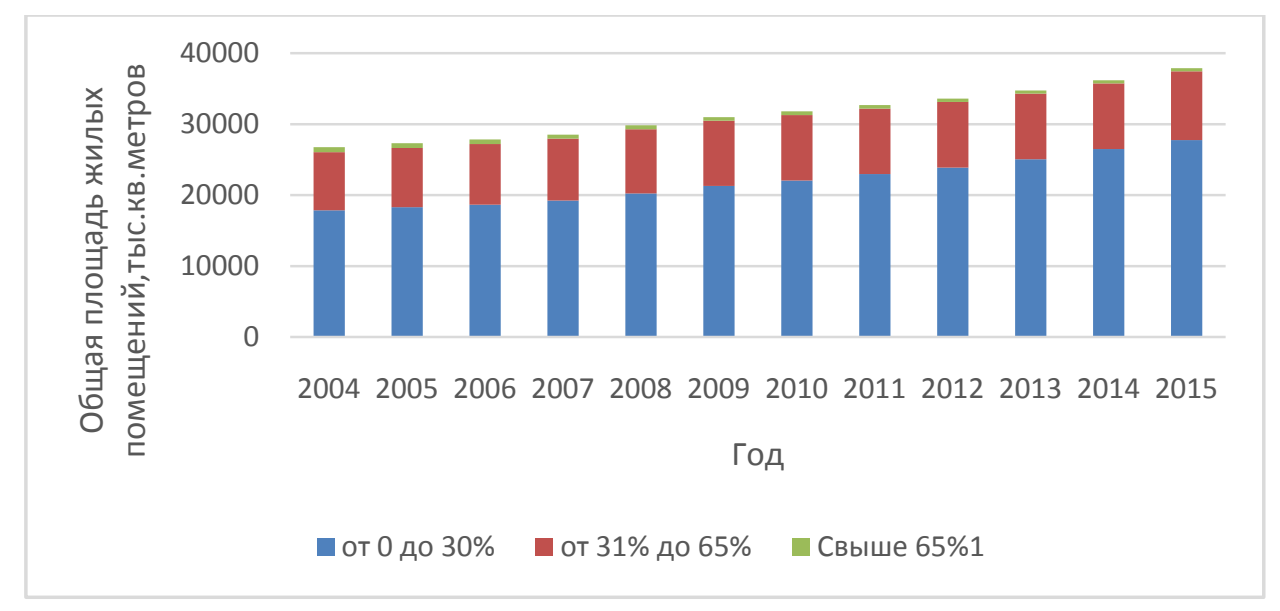

Рис.1 - Процент износа жилого фонда г. Новосибирска.

Как видно из рисунка,Новосибирску присуща тенденция старения жилых зданий города, что постепенно ведет к потере жилищного фонда.

Чтобы предотвратить потерю жилищного фонда необходимо на стадиях изысканий, проектирования, строительства и содержания предусматривать ряд мероприятий, нарушение которых ведет к ряду ошибок. Нашими исследованиями установлены следующие.

Ошибки инженерно-геологических изысканий

Сегодня многие специализированные изыскательские лаборатории некогда крупных проектных институтов закрыты и не работают. В свою очередь Заказчики заинтересованы в проведении дешевых изысканий в малом объеме и в сжатые сроки. В процессе изысканий мест застройки, сложенных слабыми, просадочными, техногенными, сильно-сжимаемыми грунтами, глубина скважин не достаточна для прохождения эти грунтов. Ошибки допускаются при отборе образцов в указанных специфических грунтах.

Образцы из просадочных грунтов при изысканиях далеко не всегда отбираются правильно.Неправильно отобранные образцы в скважинах приводят к занижению характеристик просадочности. Часты случаи деформации зданий из-за не правильных характеристик исследованных образцов грунтов на просадочность и набухание. 
При возведении нового строительства на ранее занимаемых площадях под частный сектор находились многочисленные погреба и выгребные ямы, колодцы. Такие участки не исследуются.

Изыскательские организации не всегда дают инженерно-геологические условия площадки на период строительства. Применительно к условиям г. Новосибирска - это площадки, имеющие угрозу подтопления со сложными просадочными грунтами.

Ошибки инженерно-геологических изысканий трудно поддаются учету, так как они проявляются в период строительства и дальнейшей эксплуатации зданий.

\section{Ошибки при проектировании}

При проектировании не учитывается эволюция грунтов в инженерногеологических условиях г. Новосибирска, которая отражается на состоянии зданий в процессе их последующей эксплуатации. Основной ошибкой является отсутствие учета изменения физико-механических свойств грунтов при подъеме или понижении уровня грунтовых вод.

Много ошибок допускается при проектировании зданий, которые пристраиваются к существующим. В число ошибок входит не учет фундамента существующего здания, увеличения высоты подвальных помещений за счет выемки грунта. Перераспределяя нагрузки на фундамент без учета действительной несущей способности зачастую увеличивают этажность зданий без достаточного обоснования.

Низкое качество работ при устройстве оснований и фундаментов

Распространённые нарушения этой группы связаны с перебором, затоплением или промораживанием дна котлована, с нарушениями структуры грунта при динамических воздействиях, засыпкой пазух котлована водопроницаемым грунтом, неоправданными простоями разработанных котлованов, не правильным осуществлением водопонижения способом открытого водоотлива в мелкодисперсных грунтах [4]. В последние время часто 
встречаются нарушения, связанные с неудовлетворительной консервацией при длительных перерывах в строительстве.

Встречаются случаи, когда неправильно выбранная технология производства работ приводит к отступлению от проекта. Часто разработка котлованов под новое строительство вблизи существующих зданий выполняется без крепления их стенок и откосов.

\section{Эксплуатационные причины отказов}

Происходит частое замачивание грунтов, с техногенными утечками из водонесущих коммуникаций.

Помимо замачивания происходит понижение уровня грунтовых вод без достаточного обоснования и учета негативных воздействий на прилегающие здания и сооружения.

Динамические воздействия на существующие здания и сооружения, приводят к нарушениям целостности фундамента. В последние годы стали часто встречаться случаи перепланировки и реконструкции квартир без согласования с эксплуатирующими организациями. В результате происходит перераспределение нагрузок и, как следствие, дополнительные неравномерные осадки фундамента.

Решение проблемы восстановления эксплуатационной надежности деформируемых зданий без упрочнения грунтов основания и усиления самих фундаментов невозможно [2,3].

В Новосибирске освоено достаточное количество технологий связанных с упрочнением, закреплением и армированием грунтов. Появились организации освоившие один или два метода усиления грунтов основания, но упрочнение грунтов является сложным и дорогостоящим мероприятием.

В связи с отсутствием достаточного опыта при проектировании не выполняется сравнение вариантов и научно обоснованный выбор метода упрочнения применительно к конкретным грунтовым условиям. 
Основные направления обеспечения надежности оснований и фундаментовследующие[1]:

1. Проектно-изыскательская документация на все объекты нового строительства должнапроходить полную и всеобъемлющую экспертизу;

2. Стоимость экспертизы проектной документации и авторского надзора за строительством должна быть учтена в сметной стоимости строительства;

3. В проектную документацию необходимо включать раздел, посвященный анализу эволюции грунтов, изменений геологической и гидрогеологической обстановки в процессе эксплуатации здания;

4. При расчете оснований по предельным состояниям необходимо использовать характеристики грунтов в условиях их полного водонасыщения;

5. Восстановление эксплуатационной надежности деформированных зданийможет быть достигнуто путем усиления грунтов основания или фундаментов, или других приемлемых технологий;

6. В проекте упрочнения грунтов основания необходимраздел, посвященный обоснованию выбора способа закрепления;

7. При проектировании последующей надстройки зданий необходимо усиление грунтов основания. 


\section{Литература:}

1. Крицкий М.Я., Ланис А.Л., Сухорукова А.Ф., Колышкин С.В. Причины деформаций зданий и сооружений в Новосибирске // Вестник Иркутского государственного технического университета. № 1. 2005. с. 20 - 24

2. М.Я. Крицкий, А.Ф. Сухорукова, С.И. Черноусов. Особенности инженерно-геологических условий г. Новосибирска и пути создания надежных грунтовых оснований. Город. Прошлое, настоящее, будущее. Проблемы развития и управления на пороге III тысячелетия. Иркутск, 2000 г, c. 90-94.

3. М.Я. Крицкий, А.Ф. Сухорукова, А.В. Лубягин. Пути решения проблемы усиления грунтовых оснований объектов с учетом инженерногеологических условий г. Новосибирска. Материалы международного симпозиума "Инженерно - геологические проблемы урбанизированных территорий", г. Екатеринбург, 30 июля-2 августа 2001 г., т. 2, с. 727-731

4. Патент на полезную модель № 143618. Устройство для крепления котлована / П.С. Пинчук, В.С. Воробьев, Н.П. Запащикова, С.Н. Распопин, Е.П. Пинчук; СГУПС. - Зарегистрировано в Государственном реестре изобретений РФ № 143618 от 25.06.2014 г.

5. https://sibgrad.com/index.php/news/obshestvo/834-obsuzhdenie-roblemgoroda-na-forume-kprf. 